\title{
The selective electrochemical fluorination of $S$-alkyl benzothioate and its derivatives
}

\author{
Shunsuke Kuribayashi ${ }^{1}$, Tomoyuki Kurioka ${ }^{2}$, Shinsuke Inagi ${ }^{2}$, Ho-Jung Lu ${ }^{3}$, \\ Biing-Jiun Uang ${ }^{3}$ and Toshio Fuchigami ${ }^{* 1}$
}

\section{Letter}

\section{Address:}

${ }^{1}$ Department of Electronic Chemistry, Tokyo Institute of Technology, 4259 Nagatsuta-cho, Midori-ku, Yokohama 226-8502, Japan,

${ }^{2}$ Department of Chemical Science and Engineering, School of Materials and Chemical Technology, Tokyo Institute of Technology, 4259 Nagatsuta-cho, Midori-ku, Yokohama 226-8502, Japan and ${ }^{3}$ Department of Chemistry, National Tsing Hua University, 101, Sec 2 Kuang Fu Rd., Hsinchu 300, Taiwan, R.O.C

Email:

Toshio Fuchigami ${ }^{*}$ - fuchi@echem.titech.ac.jp

* Corresponding author

Keywords:

anodic cyclization; diastereoselective fluorination; electrosynthesis;

fluorobenzothiophenone; selective fluorination
Beilstein J. Org. Chem. 2018, 14, 389-396.

doi:10.3762/bjoc. 14.27

Received: 30 October 2017

Accepted: 17 January 2018

Published: 12 February 2018

This article is part of the Thematic Series "Electrosynthesis II".

Guest Editor: S. R. Waldvogel

(c) 2018 Kuribayashi et al.; licensee Beilstein-Institut. License and terms: see end of document.

\begin{abstract}
We herein report that the regioselective anodic fluorination of $S$-alkyl benzothioate and its derivatives in various aprotic solvents using $\mathrm{Et}_{3} \mathrm{~N} \cdot n \mathrm{HF}(n=3-5)$ and $\mathrm{Et}_{4} \mathrm{NF} \cdot n \mathrm{HF}(n=3-5)$ as supporting electrolyte and a fluorine source successfully provided the corresponding $\alpha$-fluorinated products in moderate yields. Dichloromethane containing $\mathrm{Et}_{4} \mathrm{NF} \cdot 4 \mathrm{HF}$ was found to be the most suitable combination as electrolytic solvent and supporting salt as well as fluorine source for the anodic fluorination. The electrochemical fluorination of cyclic benzothioates such as benzothiophenone was also achieved.
\end{abstract}

\section{Introduction}

Due to the interesting properties of fluorine atoms and carbon-fluorine bonds, organofluorine compounds are widely used in various fields like pharmaceutical chemistry, agrochemistry, and materials sciences $[1,2]$. Therefore, the selective fluorination of organic compounds is highly useful for the development of novel organofluorine compounds. Although a number of fluorination reagents have been developed so far, they have still some problems, i.e., they are costly, difficult to handle, and explosive $[3,4]$. On the other hand, Rozhkov and Laurent reported an electrochemical partial fluorination of naphthalene and olefins about 30 years ago $[5,6]$. However, at that time, there has been no report on the anodic fluorination of heteroatom-containing compounds. At almost the same time, we found that the anodic $\alpha$-methoxylation of organosulfur and amino compounds was generally enhanced by the presence of an $\alpha$-electron-withdrawing group (EWG) such as a $\mathrm{CF}_{3}$ group. 
Here, the deprotonation of an anodically generated radical cation intermediate is accelerated by an EWG $[7,8]$. Based on these facts, we successfully achieved the first anodic fluorination of sulfides having various EWGs at their $\alpha$-position using $\mathrm{Et}_{3} \mathrm{~N} \cdot 3 \mathrm{HF}[9,10]$. Since then, we have systematically studied the electrochemical fluorination of numerous organic compounds, heterocycles, and macromolecules by using various fluoride salts such as $\mathrm{Et}_{3} \mathrm{~N} \cdot n \mathrm{HF}(n=3-5)$ and $\mathrm{Et}_{4} \mathrm{NF} \cdot n \mathrm{HF}$ $(n=3-5)$ [11-19].

On the other hand, Simonet and co-workers reported the anodic fluorination of alkyl phenyl sulfides having an EWG on the phenyl group in $\mathrm{Et}_{3} \mathrm{~N} \cdot 3 \mathrm{HF} / \mathrm{MeCN}$ to provide $\alpha$-monofluorinated products in moderate yields [20]. We also achieved the anodic fluorination of benzyl and ethyl thiocyanates as well as $O$-methyl $S$-aralkyl thiocarbonates by using the anodically stable $\mathrm{Et}_{3} \mathrm{~N} \cdot 5 \mathrm{HF}$ and $\mathrm{Et}_{4} \mathrm{NF} \cdot 4 \mathrm{HF}[21,22]$. In both cases, an EWG attached to the phenyl group and the electron-withdrawing SCN group both contribute to the generation of the cation resulting in a regioselective $\alpha$-fluorination. Based on these findings, we anticipated that the $\alpha$-cationic intermediate could also be generated anodically from $S$-alkyl benzothioates. Moreover, we previously successfully carried out an anodic fluorodesulfurization of $S$-aryl thiobenzoates, and found that the indirect electrolysis using a triarylamine mediator gave much better yields of benzoyl fluorides compared to the direct electrolysis [23]. Therefore, we became interested in the anodic behavior of $S$-alkyl benzothioates in the presence of fluoride ions. With this in mind and in order to provide an additional application of our electrochemical fluorination, we have studied the anodic fluorination of $S$-alkyl benzothioate and its derivatives as well as its cyclic analogues such as benzothiophenone.

\section{Results and Discussion Oxidation potentials of $S$-butyl benzothioates}

At first, the anodic oxidation potentials of $S$-butyl benzothioate (1a), $S$-butyl $p$-chlorobenzothioate (1b), and $S$-butyl $p$-fluorobenzothioate (1c) were determinded by cyclic voltammetry (CV). The compounds did not exhibit clear oxidation peaks, however, discharge started at around $+2.3 \mathrm{~V}$ to $+2.4 \mathrm{~V}$ vs SCE as exemplified in Figure 1 (CV curves of 1a). Thus, it was found that these compounds have rather high oxidation potentials. DFT calculation of 1a indicated that the highest occupied molecular orbital (HOMO) is located at the sulfur atom (Figure 2). Although sulfur atoms are easily oxidized, the oxidation potential of 1a was found to be extremely high, that is due to the strongly electron-withdrawing benzoyl group attached to the sulfur atom. Benzyl thiocyanate is also known to be oxidized at a high potential which is similar to that of $\mathbf{1 a}$ [21].

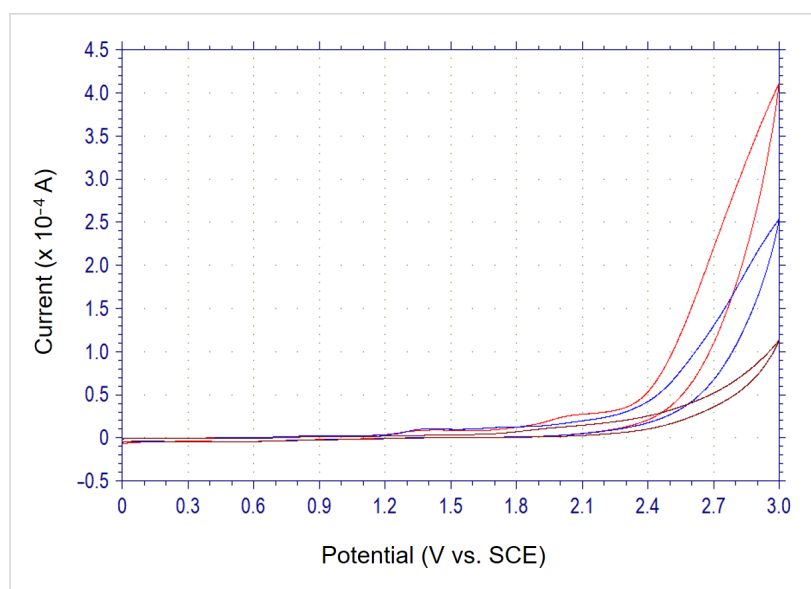

Figure 1: Cyclic voltammograms of $0.1 \mathrm{M} \mathrm{Bu}_{4} \mathrm{NBF}_{4} / \mathrm{MeCN}$ with a $\mathrm{Pt}$ disk working electrode in the absence (brown line) and presence of $5.0 \mathrm{mM}$ (blue line) and $10.0 \mathrm{mM} 1 \mathrm{a}$ (red line). Scan rate of $100 \mathrm{mV} / \mathrm{s}$.

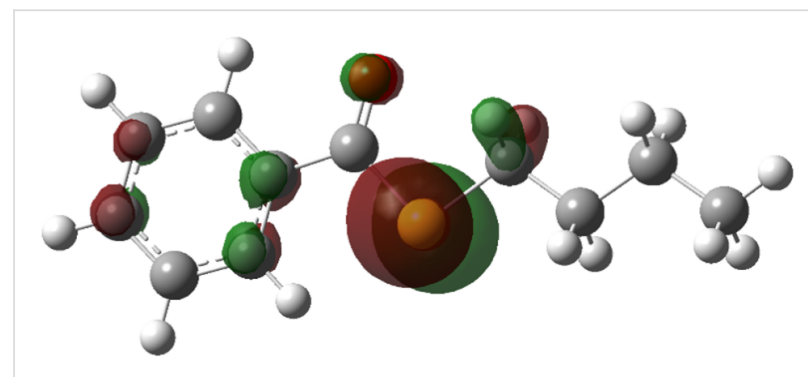

Figure 2: Calculated HOMO diagram of 1a.

\section{Anodic fluorination of S-butyl benzothioates}

Next, we carried out the anodic fluorination of 1 a as a model compound under various electrolytic conditions. Electrolysis was performed at a constant current $(40 \mathrm{~mA})$ with platinum electrodes $(2 \mathrm{~cm} \times 2 \mathrm{~cm})$ in several solvents containing various fluoride salts in an undivided cell at room temperature and current was passed basically until 1a was consumed. The results are summarized in Table 1.

Regardless of the electrolytic conditions, the anodic fluorination proceeded to provide the desired fluorinated product $\mathbf{2 a}$ except for the electrolysis performed in dimethoxyethane (DME) as the solvent (Table 1, entry 3 ). The oxidation potential of $1 \mathbf{a}$ is rather high, while that of DME is relatively low [24]. Therefore, DME seems to be oxidized prior to 1a resulting in no formation of $\mathbf{2 a}$, and $\mathbf{1 a}$ was mostly recovered even when passing the theoretical amount of electricity $(2 \mathrm{~F} / \mathrm{mol})$. Among the solvents tested, $\mathrm{CH}_{2} \mathrm{Cl}_{2}$ was found to be the best and the desired fluorinated product $\mathbf{2 a}$ was obtained in 55\% yield (Table 1, entry 1). In this case, the starting 1 a was consumed completely at $4.5 \mathrm{~F} / \mathrm{mol}$. It is well known that the fluoride salt, $\mathrm{Et}_{3} \mathrm{~N} \cdot 3 \mathrm{HF}$ is easily oxidized $\left(2.0 \mathrm{~V}\right.$ vs $\left.\mathrm{Ag} / \mathrm{Ag}^{+}\right)$ because it contains a considerable amount of free $\mathrm{Et}_{3} \mathrm{~N}$ [25]. 
Table 1: Electrochemical fluorination of S-butyl benzothioate derivatives.

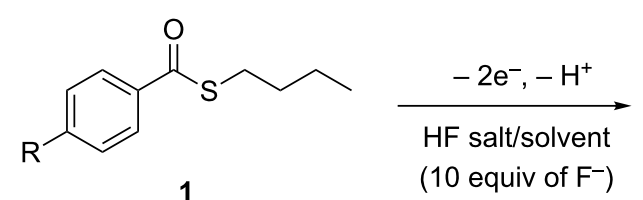

1<smiles>[R]c1ccc(C(=O)SC(F)CCC)cc1</smiles>

2
3

\begin{tabular}{|c|c|c|c|c|c|c|c|}
\hline \multirow[t]{2}{*}{ entry } & \multirow[t]{2}{*}{ compound } & \multirow[t]{2}{*}{$\mathrm{R}$} & \multirow[t]{2}{*}{ supporting electrolyte } & \multirow[t]{2}{*}{ solvent } & \multirow[t]{2}{*}{ electricity $(\mathrm{F} / \mathrm{mol})$} & \multicolumn{2}{|c|}{ yield $(\%)^{a}$} \\
\hline & & & & & & 2 & 3 \\
\hline 1 & $1 a$ & $\mathrm{H}$ & $\mathrm{Et}_{3} \mathrm{~N} \cdot 3 \mathrm{HF}$ & $\mathrm{CH}_{2} \mathrm{Cl}_{2}$ & 4.5 & 55 & - \\
\hline 2 & $1 a$ & $\mathrm{H}$ & $\mathrm{Et}_{3} \mathrm{~N} \cdot 3 \mathrm{HF}$ & $\mathrm{CH}_{3} \mathrm{CN}$ & 7.0 & 26 & - \\
\hline 3 & $1 \mathrm{a}$ & $\mathrm{H}$ & $\mathrm{Et}_{3} \mathrm{~N} \cdot 3 \mathrm{HF}$ & DME & 2.0 & $0^{\mathrm{b}}$ & - \\
\hline 4 & $1 \mathrm{a}$ & $\mathrm{H}$ & $\mathrm{Et}_{3} \mathrm{~N} \cdot 3 \mathrm{HF}$ & $\mathrm{CH}_{3} \mathrm{NO}_{2}$ & 7.0 & 29 & - \\
\hline 5 & $1 a$ & $\mathrm{H}$ & $\mathrm{Et}_{3} \mathrm{~N} \cdot 4 \mathrm{HF}$ & $\mathrm{CH}_{2} \mathrm{Cl}_{2}$ & 4.5 & 56 & - \\
\hline 6 & $1 \mathrm{a}$ & $\mathrm{H}$ & $\mathrm{Et}_{3} \mathrm{~N} \cdot 5 \mathrm{HF}$ & $\mathrm{CH}_{2} \mathrm{Cl}_{2}$ & 4.0 & 43 & - \\
\hline 7 & $1 a$ & $\mathrm{H}$ & $\mathrm{Et}_{4} \mathrm{NF} \cdot 3 \mathrm{HF}$ & $\mathrm{CH}_{2} \mathrm{Cl}_{2}$ & 5.4 & 57 & - \\
\hline 8 & $1 a$ & $\mathrm{H}$ & $\mathrm{Et}_{4} \mathrm{NF} \cdot 4 \mathrm{HF}$ & $\mathrm{CH}_{2} \mathrm{Cl}_{2}$ & 4.0 & 55 & - \\
\hline 9 & $1 \mathrm{a}$ & $\mathrm{H}$ & $\mathrm{Et}_{4} \mathrm{NF} \cdot 5 \mathrm{HF}$ & $\mathrm{CH}_{2} \mathrm{Cl}_{2}$ & 4.0 & 38 & - \\
\hline $10^{c}$ & $1 \mathrm{a}$ & $\mathrm{H}$ & $\mathrm{Et}_{4} \mathrm{NF} \cdot 4 \mathrm{HF}$ & $\mathrm{CH}_{2} \mathrm{Cl}_{2}$ & 4.0 & $67(61)$ & 12 \\
\hline $11^{\mathrm{c}}$ & $1 b$ & $\mathrm{Cl}$ & $\mathrm{Et}_{4} \mathrm{NF} \cdot 4 \mathrm{HF}$ & $\mathrm{CH}_{2} \mathrm{Cl}_{2}$ & 6.0 & $51(45)$ & 20 \\
\hline $12^{\mathrm{c}}$ & $1 c$ & $\mathrm{~F}$ & $\mathrm{Et}_{4} \mathrm{NF} \cdot 4 \mathrm{HF}$ & $\mathrm{CH}_{2} \mathrm{Cl}_{2}$ & 4.0 & $60(50)$ & 9 \\
\hline
\end{tabular}

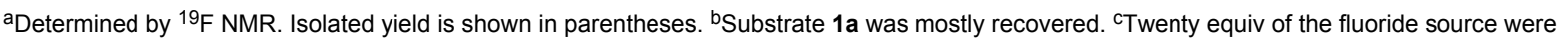
used.

However, the fluorination proceeded well particularly in a $\mathrm{CH}_{2} \mathrm{Cl}_{2}$ solution containing $\mathrm{Et}_{3} \mathrm{~N} \cdot 3 \mathrm{HF}$. In contrast, when $\mathrm{MeCN}$ and $\mathrm{MeNO}_{2}$ were used as an electrolytic solvent, the yield was decreased considerably (Table 1 , entries 2 and 4 ). This is because of a low conversion of $\mathbf{1 a}$ in these solvents and indeed a large amount of $\mathbf{1 a}$ was recovered.

Subsequently the effect of different fluoride salts on the fluorination was investigated similarly (Table 1, entries 5-9). Regardless of the fluoride salts, product 2a was obtained in moderate yield, however, using $\mathrm{Et}_{4} \mathrm{NF} \cdot 4 \mathrm{HF}$ gave the best current efficiency for the formation of $\mathbf{2 a}$ (Table 1, entry 8). Increasing the amount of $\mathrm{Et}_{4} \mathrm{NF} \cdot 4 \mathrm{HF}$ from 10 to 20 equiv, the product yield was also increased from $55 \%$ to $67 \%$ (Table 1 , entry 10 ). However, in this case, $\mathrm{C}-\mathrm{S}$ bond cleavage also took place to form benzoyl fluoride (3a) as a byproduct in considerable amounts. In all cases, no fluorination at the phenyl group took place.

Then, this anodic fluorination was extended to $p$-chloro- and $p$-fluorobenzothioates, (1b) and (1c), using 20 equiv of $\mathrm{Et}_{4} \mathrm{NF} \cdot 4 \mathrm{HF}$ as the supporting electrolyte (Table 1, entries 11 and 12). In both cases, a fluorine atom was introduced selectively to the $\alpha$-position to provide $\mathbf{2 b}$ and $\mathbf{2 c}$ in moderate yields. However, the corresponding benzoyl fluorides $\mathbf{3 b}$ and $\mathbf{3 c}$ were also formed similarly to the case of $\mathbf{1 a}$.

\section{Anodic fluorination of $S$-( $\omega$-substituted alkyl) benzylthioates}

Initially, the oxidation potentials of various $S$-(substituted alkyl) benzylthioates $\mathbf{1 d}-\mathbf{j}$ were determined by $\mathrm{CVs}$ in $0.1 \mathrm{M}$ $\mathrm{Bu}_{4} \mathrm{NBF}_{4} / \mathrm{MeCN}$ similarly to the case of $\mathbf{1 a}$ and the results are collected in Table 2. Unexpectedly, no relationship between the substituents and the oxidation potentials could be observed. Next, the anodic fluorination of $\mathbf{1} \mathbf{d}-\mathbf{j}$ was carried out at a constant current in $\mathrm{Et}_{4} \mathrm{NF} \cdot 4 \mathrm{HF} / \mathrm{CH}_{2} \mathrm{Cl}_{2}$ and the results are summarized also in Table 2 .

Regardless of the substituents, the anodic fluorination took place to afford the corresponding $\alpha$-fluorinated products $\mathbf{2}$ in moderate to reasonable yields along with benzoyl fluoride as byproduct (Table 2). Generally, no fluorination of the phenyl ring was observed. In the case of $\mathbf{1 h}$, electron transfer seems to take place from both the sulfur atom and the $\alpha$-phenyl group, which was suggested by DFT calculation (Figure 3). However, regardless of the discharging sites, the same cationic intermediate is generated through two-electron oxidation and deprotonation (in $\alpha$ position to both the sulfur atom and phenyl group), which forms the $\alpha$-fluorinated product $\mathbf{2 h}$ selectively. In contrast, the electron transfer of $\mathbf{1 i}$ seems to take place mainly from the $\beta$-phenyl group as indicated by DFT calculation (Figure 3). As shown in Scheme 1, an electron transfer from the 
Table 2: Oxidation potentials and electrochemical fluorination of S-substituted alkyl benzothioates.<smiles>[R]CSC(=O)c1ccccc1</smiles>

1

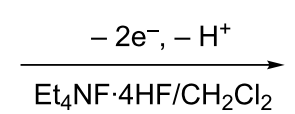

(20 equiv of $\mathrm{F}^{-}$)<smiles>[R]C(F)SC(=O)c1ccccc1</smiles>

2
3

\begin{tabular}{|c|c|c|c|c|c|c|}
\hline \multirow[t]{2}{*}{ entry } & \multirow[t]{2}{*}{ compound } & \multirow[t]{2}{*}{$\mathrm{R}$} & \multirow{2}{*}{$\begin{array}{l}\text { oxidation potential } \\
\text { (V vs SCE) }\end{array}$} & \multirow[t]{2}{*}{ electricity (F/mol) } & \multicolumn{2}{|c|}{ yield $(\%)^{a}$} \\
\hline & & & & & 2 & 3 \\
\hline 1 & $1 a$ & $n-\operatorname{Pr}-$ & 2.3 & 4.0 & $67(61)$ & 12 \\
\hline 2 & $1 d$ & $\mathrm{NCCH}_{2} \mathrm{CH}_{2-}$ & 2.1 & 6.0 & $43(35)$ & 12 \\
\hline 3 & $1 e$ & $\mathrm{MeOCH}_{2} \mathrm{CH}_{2-}$ & 2.0 & 6.0 & $33(29)$ & 19 \\
\hline 4 & $1 f$ & EtOOC- & 2.2 & 6.0 & $36(29)$ & 12 \\
\hline 5 & $1 \mathrm{~g}$ & $\mathrm{HC} \equiv \mathrm{C}-$ & 2.3 & 8.0 & $40(37)$ & 10 \\
\hline 6 & $1 \mathrm{~h}$ & $\mathrm{Ph}-$ & 2.1 & 4.0 & $56(46)$ & 5 \\
\hline 7 & $1 \mathbf{i}$ & $\mathrm{PhCH}_{2-}$ & 2.2 & 6.0 & $10(7)$ & 5 \\
\hline 8 & $1 \mathrm{j}$ & $p-\mathrm{CF}_{3} \mathrm{C}_{6} \mathrm{H}_{4} \mathrm{CH}_{2^{-}}$ & 2.1 & 6.0 & $48(40)$ & 12 \\
\hline
\end{tabular}

Determined by ${ }^{19} \mathrm{~F}$ NMR. Isolated yields are shown in parentheses.

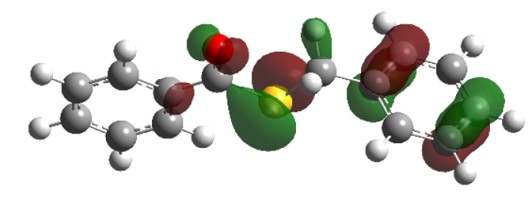

1h

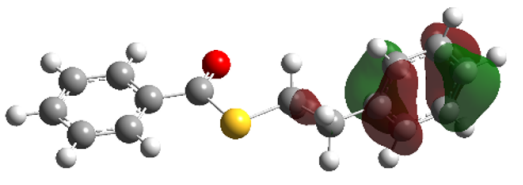

$1 \mathrm{i}$

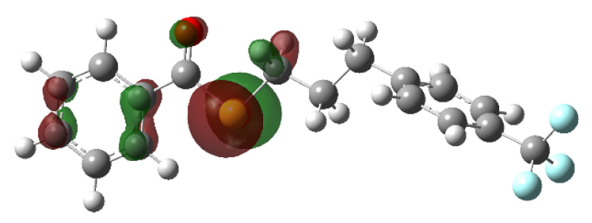

1j

Figure 3: Calculated HOMO diagrams of $\mathbf{1 h}, \mathbf{1} \mathbf{i}$ and $\mathbf{1 j}$.

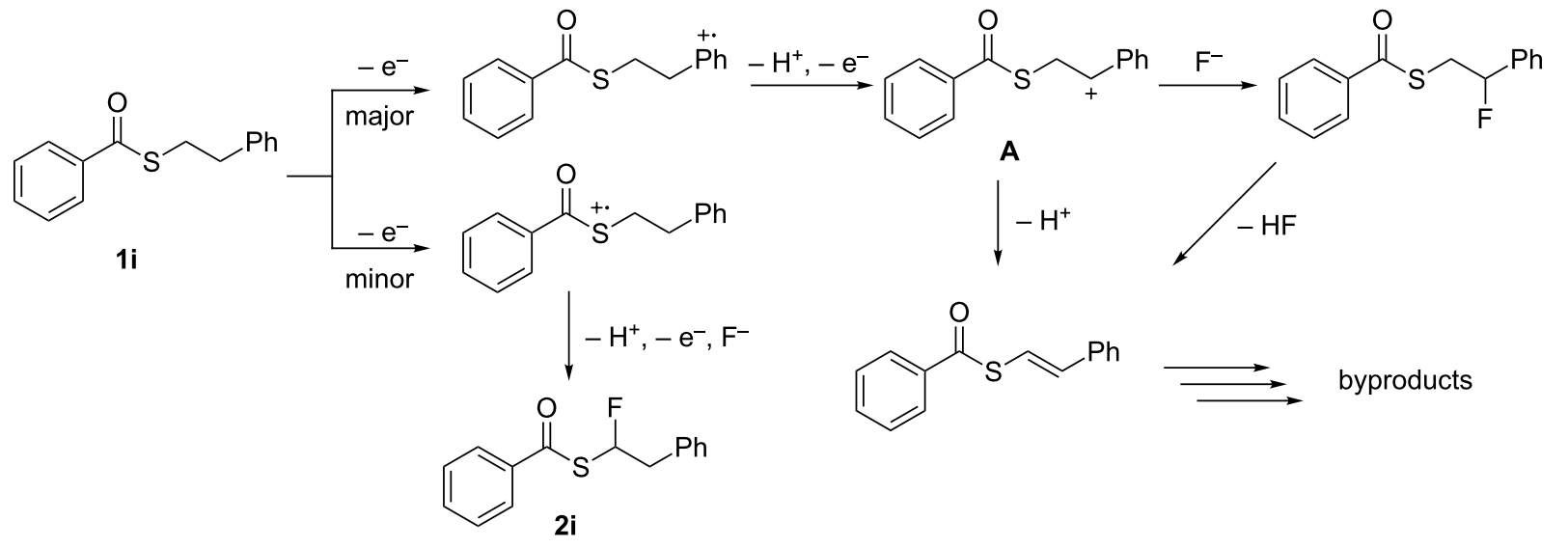

Scheme 1: Plausible reaction paths of the anodic oxidation of $1 \mathrm{i}$ in $\mathrm{Et} 4 \mathrm{NF} \cdot 4 \mathrm{HF} / \mathrm{CH}_{2} \mathrm{Cl}_{2}$. 
$\beta$-phenyl group in 1i followed by deprotonation and an additional electron transfer generates the benzylic cationic intermediate $\mathbf{A}$, which affords the benzylic fluorinated product. It is known that benzylic fluorinated compounds are known to be generally prone to lose a fluoride anion [26]. On the other hand, intermediate A may undergo also elimination of a $\beta$-proton due to the electron-withdrawing benzothioate group prior to the reaction with fluoride as reported before [27]. As a consequence the expected $\alpha$-fluorinated product $2 \mathbf{i}$ was formed in an only low yield of $10 \%$.

In order to suppress the discharge from the $\beta$-phenyl group of 1i, a strongly electron-withdrawing $\mathrm{CF}_{3}$ group was introduced in the para-position of the phenyl group. The HOMO of $\mathbf{1} \mathbf{j}$ was found to be located mainly at the sulfur atom as determined by DFT calculation (Figure 3). As expected, the anodic fluorination proceeded to provide the $\alpha$-fluorinated product $2 \mathbf{j}$ in a moderate yield of $48 \%$.

Next, the anodic fluorination was performed with the benzothioate derivative $1 \mathbf{k}$ having a camphor group as a chiral auxiliary. The anodic fluorination proceeded to afford the corresponding $\alpha$-fluoro products as a diastereoisomeric mixture ( $43 \%$ de) in a reasonable yield $42 \%$ along with benzoyl fluoride as byproduct (Scheme 2).

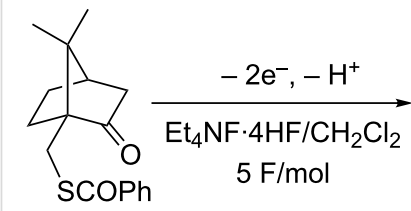

$1 \mathrm{k}$

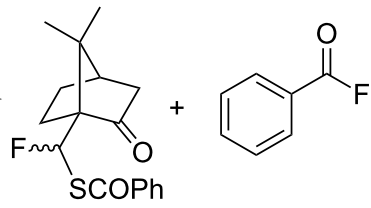

$2 k$

3
$42 \%\left({ }^{19} \mathrm{~F}\right.$ NMR yield) $\quad 10 \%$

$35 \%$ (isolated yield)

$43 \%$ de

Scheme 2: Anodic fluorination of $\mathbf{1 k}$.

We next also carried out the anodic fluorination of a cyclic benzothioate namely benzothiophenone $\mathbf{1 1}$. In this case, the fluorination took place predominantly at the benzylic position to

afford the fluorinated product $2 \mathrm{I}$ in $60 \%$ isolated yield (Scheme 3). With this substrate, neither $\mathrm{C}-\mathrm{S}$ bond cleavage nor benzene ring fluorination took place at all.

$$
\begin{aligned}
& \text { } \frac{\mathrm{Et} \mathrm{N}_{4} \mathrm{NF} \cdot 4 \mathrm{HF} / \mathrm{CH}_{2} \mathrm{Cl}_{2}}{4 \mathrm{~F} / \mathrm{mol}^{-}} \\
& 11 \\
& \text { 21 } \\
& 62 \%\left({ }^{19} \mathrm{~F}\right. \text { NMR yield) } \\
& 60 \% \text { (isolated yield) }
\end{aligned}
$$

Scheme 3: Anodic fluorination of cyclic derivative 11.

Finally, the anodic fluorination of benzothioates having a $\gamma$ and $\delta$-carboxyl group, $1 \mathbf{m}$ and $\mathbf{1 n}$, was examined. The anodic oxidation of $1 \mathbf{m}$ and $1 \mathrm{n}$ proceeded; however, $\alpha$-fluorination did not occur. In both cases, an anodic intramolecular cyclization took place to give the corresponding lactone derivatives in reasonable yields as shown in Scheme 4.

\section{Reaction mechanism}

In the cases of open-chain benzothioate derivatives, the anodic fluorination is initiated by an electron transfer occurring mainly from the sulfur atom of the benzothioates following two pathways (Scheme 5). The main pathway comprises the elimination of an $\alpha$-proton, which is facilitated by the presence of an electron-withdrawing benzoyl group followed by another one-electron oxidation to generate a cationic intermediate which upon reaction with fluoride forms the $\alpha$-fluorinated products. On the other hand, a minor pathway involves a $\mathrm{C}-\mathrm{S}$ bond cleavage to form benzoyl fluoride as is observed in the case of the anodic oxidation of $S$-aryl benzothioates [23].

In the case of $S$-alkyl benzothioates bearing a carboxyl group at the $\gamma$ and $\delta$-position with respect to the sulfur atom, after generation of an $\alpha$-cationic intermediate, the intramolecular cyclization seems to take place faster than combination with a fluoride ion as shown in Scheme 6. In support of this, we have reported a fluoride ion-promoted anodic cyclization of $\alpha$-(phenylthio)- $N$ phenyl- and $\alpha$-(phenylthio)- $N$-benzylacetamides [28] as well as

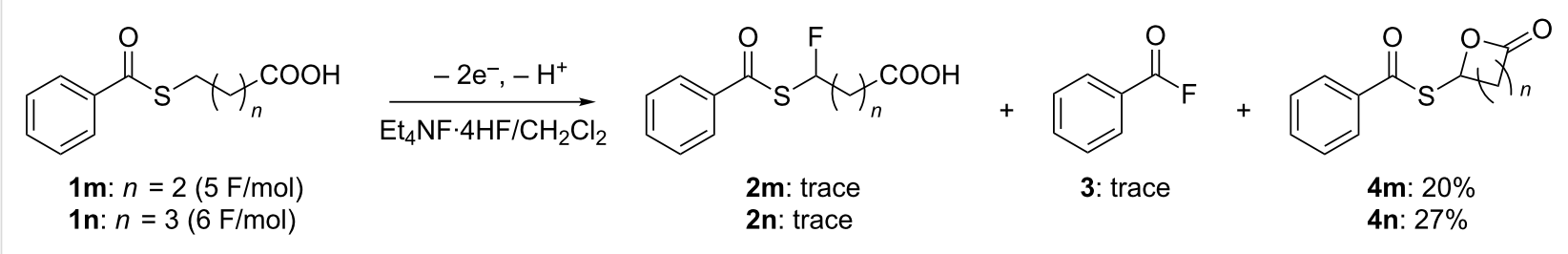

Scheme 4: Anodic oxidation of $1 \mathrm{~m}$ and $1 \mathrm{n}$ in $\mathrm{Et}{ }_{4} \mathrm{NF} \cdot 4 \mathrm{HF} / \mathrm{CH}_{2} \mathrm{Cl}_{2}$. 


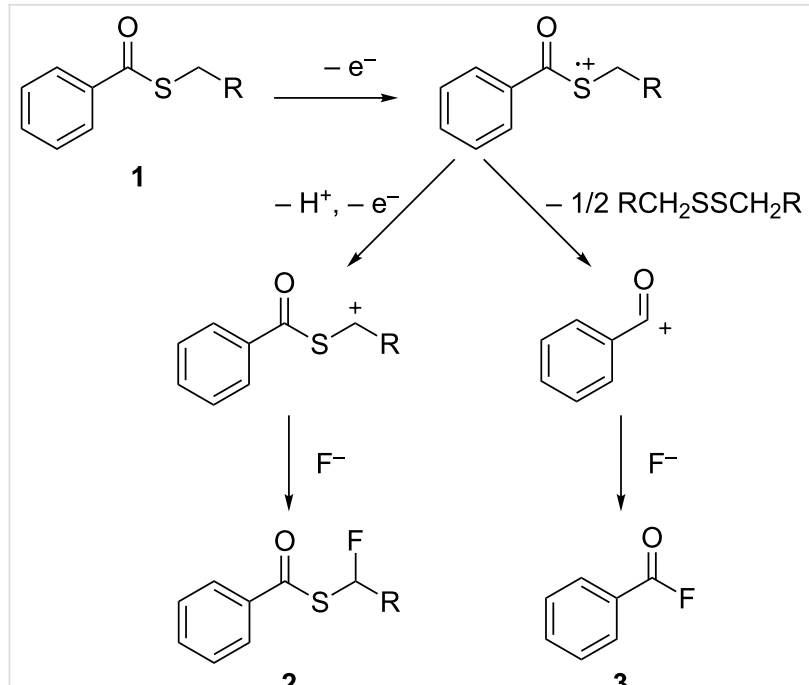

Scheme 5: General reaction mechanism for the anodic fluorination of 1.

2-(tert-butoxycarbonyl)oxy-3,3,3-trifluoropropyl phenyl sulfide [29].

\section{Conclusion}

In summary, we have achieved the regioselective anodic fluorination of various $S$-alkyl and $S$-substituted alkyl benzothioate derivatives in $\mathrm{Et}_{4} \mathrm{NF} \cdot 4 \mathrm{HF} / \mathrm{CH}_{2} \mathrm{Cl}_{2}$ and a fluorine atom was selectively introduced in the $\alpha$-position to the sulfur atom. Under the conditions, a camphor-substituted analogue was anodically fluorinated with moderate diastereoselectivity. Moreover, the anodic fluorination of a cyclic benzothioate such as benzothiophenone was also successfully demonstrated. In contrast, the anodic fluorination of $S$-( $\omega$-carboxy)alkyl benzothioates afforded intramolecular cyclization products like lactones instead of the corresponding $\alpha$-fluorinated products.

\section{Experimental}

\section{General information}

${ }^{1} \mathrm{H},{ }^{13} \mathrm{C}$ and ${ }^{19} \mathrm{~F}$ NMR spectra were recorded on a JEOL JNM EX-270 ( $\left.{ }^{1} \mathrm{H}: 270 \mathrm{MHz},{ }^{13} \mathrm{C}: 67.8 \mathrm{MHz},{ }^{19} \mathrm{~F}: 254.05 \mathrm{MHz}\right)$ spectrometer in $\mathrm{CDCl}_{3}$. The chemical shifts for ${ }^{1} \mathrm{H},{ }^{13} \mathrm{C}$ and ${ }^{19} \mathrm{~F}$ NMR spectra are given in $\delta(\mathrm{ppm})$ from internal TMS,
$\mathrm{CDCl}_{3}$ and monofluorobenzene, respectively. Cyclic voltammetry was performed using an ALS Instrument model 600A. Preparative electrolysis experiments were carried out with Metronnix Corp. (Tokyo) constant current power supply model 5944 by monitoring electricity with a Hokutodenko Coulomb/ Ampere-hour meter HF-201.

\section{Cyclic voltammetry measurements}

Cyclic voltammetry was carried out in $0.1 \mathrm{M} \mathrm{Bu}_{4} \mathrm{NBF}_{4} / \mathrm{MeCN}$ using a glass cell. A platinum disk electrode $(\varnothing=0.8 \mathrm{~mm})$ was used as a working electrode. A platinum plate $(1 \mathrm{~cm} \times 1 \mathrm{~cm})$ was used as a counter electrode and a saturated calomel electrode was used as a reference electrode. Electrolyte solutions for cyclic voltammetry were deoxygenated with bubbling $\mathrm{N}_{2}$ gas before use.

\section{Materials}

The starting materials were prepared according to the literature procedures [21,23,30,31]. The known compounds, 1a,1b [32], 1c [33], 1f-1h [34], 1i [35], 1k [36], 11 [31], 1m [37] and 1n [38] were characterized by comparison of the spectral data with those reported in the literature.

\section{General procedure for the anodic fluorination}

Analogous as described in [17], the anodic oxidation of a substrate $(1 \mathrm{mmol})$ was carried out in a plastic undivided cell equipped with platinum anode and cathode $(2 \mathrm{~cm} \times 2 \mathrm{~cm})$ containing $10 \mathrm{~mL}$ of HF salt (20 equiv of $\mathrm{F}^{-}$to substrate/solvent) at room temperature. A constant current (40 mA) was passed until the starting material was mostly consumed (monitored by TLC). After electrolysis, the electrolytic solution was passed through a short column filled with silica gel using EtOAc as an eluent to remove the HF salt. The fluorinated product was further purified by silica gel column or preparative thin layer chromatography using a solution of hexane/EtOAc (20:1 to 1:1) as an eluent. The yield of the fluorinated products were estimated by ${ }^{19} \mathrm{~F}$ NMR using monofluorobenzene as an internal standard. The known fluorinated products, benzoyl fluoride [39], $p$-chlorobenzoyl fluoride [40] and $p$-fluorobenzoyl fluoride [41] were identified by comparison with ${ }^{19} \mathrm{~F}$ NMR and MS spectral data of the authentic samples.

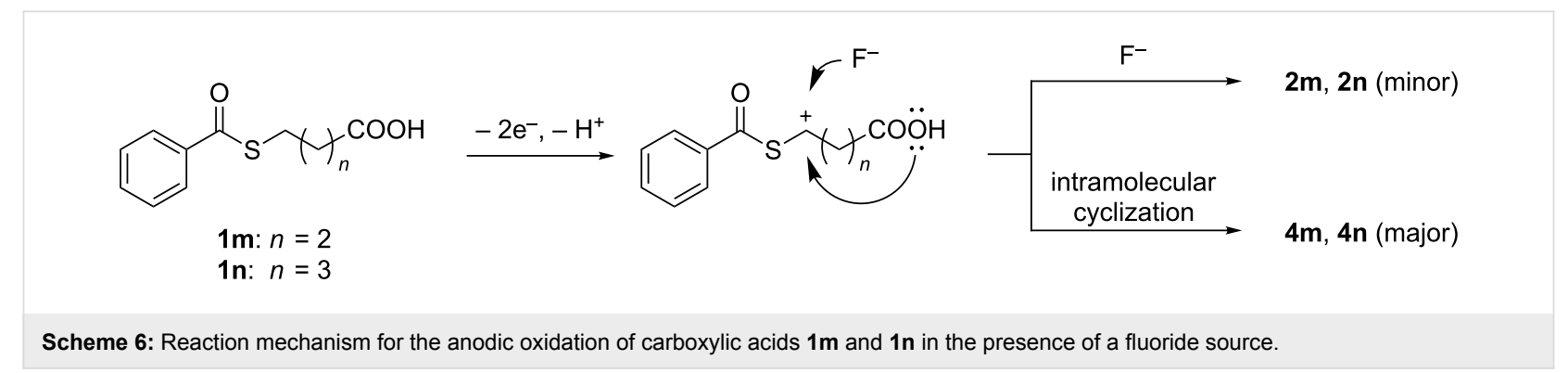




\section{Supporting Information}

\section{Supporting Information File 1}

Characterization data.

[https://www.beilstein-journals.org/bjoc/content/

supplementary/1860-5397-14-27-S1.pdf]

\section{Acknowledgements}

We gratefully acknowledge Morita Chemical Industries Co., Ltd for supplying triethylamine poly(hydrogen fluoride) $\left[\mathrm{Et}_{3} \mathrm{~N} \cdot n \mathrm{HF}(n=3-5)\right]$ and tetraethylammonium fluoride poly(hydrogen fluoride) $\left[\mathrm{Et}_{4} \mathrm{NF} \cdot n \mathrm{HF}(n=3-5)\right]$ used as supporting salt fluorine source.

\section{ORCID ${ }^{\circledR}$ iDs}

Shinsuke Inagi - https://orcid.org/0000-0002-9867-1210

\section{References}

1. Purser, S.; Moore, P. R.; Swallow, S.; Gouvermeur, V. Chem. Soc. Rev. 2008, 37, 320-330. doi:10.1039/b610213c

2. Boschet, F.; Ameduri, B. Chem. Rev. 2014, 114, 927-980. doi:10.1021/cr2002933

3. Umemoto, T.; Singh, R. P.; Xu, Y.; Saito, N. J. Am. Chem. Soc. 2010, 132, 18199-18205. doi:10.1021/ja106343h

4. Tang, P.; Wang, W.; Ritter, T. J. Am. Chem. Soc. 2011, 133, 11482-11484. doi:10.1021/ja2048072

5. Rozhkov, I. N. In Organic Electrochemistry, 2nd ed.; Baizer, M. M.; Lund, H., Eds.; chapter 24; Marcel Decker: New York, 1983.

6. Laurent, E.; Marquet, B.; Tardivel, R.; Thiebault, H. Bull. Soc. Chim. Fr. 1986, 955-964.

7. Fuchigami, T.; Nakagawa, Y.; Nonaka, T. Tetrahedron Lett. 1986, 27, 3869-3872. doi:10.1016/S0040-4039(00)83902-7

8. Fuchigami, T.; Nakagawa, Y.; Nonaka, T. J. Org. Chem. 1987, 52, 5489-5491. doi:10.1021/jo00233a043

9. Fuchigami, T.; Shimojo, M.; Konno, A.; Nakagawa, K. J. Org. Chem. 1990, 55, 6074-6075. doi:10.1021/jo00312a006

10. Konno, A.; Nakagawa, K.; Fuchigami, T. J. Chem. Soc., Chem. Commun. 1991, 1027-1029. doi:10.1039/C39910001027

11. Fuchigami, T. In Organic Electrochemistry, 4th ed.; Lund, $\mathrm{H}$.; Hammerich, O., Eds.; chapter 25; Marcel Dekker: New York, 2001.

12. Noel, M.; Suryanarayanan, V. J. Appl. Electrochem. 2004, 34 , 357-369. doi:10.1023/B:JACH.0000016670.97434.c7

13. Dawood, K. M. Tetrahedron 2004, 60, 1435-1451. doi:10.1016/j.tet.2003.11.017

14. Fuchigami, T.; Inagi, S. Chem. Commun. 2011, 47, 10211-10223. doi:10.1039/C1CC12414E

15. Fuchigami, T.; Inagi, S. In Organic Electrochemistry,, 5th ed.; Hammerich, O.; Speiser, B., Eds.; chapter 20; CRC Press: Boca Raton, FL, 2015.

16. Fuchigami, T.; Inagi, S. Organic Electrosynthesis. In Fundamentals and Applications of Organic Electrochemistry; Fuchigami,, T.; Atobe, M.; Inagi, S., Eds.; chapter 5; Wiley: West Sussex, 2015. doi:10.1002/9781118670750.ch05
17. Kuribayashi, S.; Shida, N.; Inagi, S.; Fuchigami, T. Tetrahedron 2016, 72, 5343-5349. doi:10.1016/j.tet.2016.07.016

18. Tanigawa, M.; Kuriyama, Y.; Inagi, S.; Fuchigami, T. Electrochim. Acta 2016, 199, 314-318. doi:10.1016/j.electacta.2016.02.051

19. Suzuki, J.; Shida, N.; Inagi, S.; Fuchigami, T. Electroanalysis 2016, 28, 2797-2801. doi:10.1002/elan.201600130

20. Boroux, P.; Tardivel, R.; Simonet, J. J. Electrochem. Soc. 1997, 144, 841-847. doi:10.1149/1.1837498

21. Hou, Y.; Higashiya, S.; Fuchigami, T. Electrochim. Acta 2000, 45, 3005-3010. doi:10.1016/S0013-4686(00)00379-0

22. Cao, Y.; Fuchigami, T. J. Electroanal. Chem. 2006, 587, 25-30. doi:10.1016/j.jelechem.2005.10.010

23. Shen, Y.; Suzuki, K.; Atobe, M.; Fuchigami, T. J. Electroanal. Chem. 2003, 540, 189-194. doi:10.1016/S0022-0728(02)01297-4

24. Hou, Y.; Fuchigami, T. J. Electrochem. Soc. 2000, 147, 4567-4572. doi:10.1149/1.1394102

25. Chen, S.-Q.; Hatakeyama, T.; Fukuhara, T.; Hara, S.; Yoneda, N. Electrochim. Acta 1997, 42, 1951-1960. doi:10.1016/S0013-4686(97)85466-7

26. Fuchigami, T.; Shimojo, M.; Konno, A. J. Org. Chem. 1995, 60, 3459-3464. doi:10.1021/jo00116a037

27. Erian, A. W.; Konno, A.; Fuchigami, T. J. Org. Chem. 1995, 60, 7654-7659. doi:10.1021/jo00128a044

28. Shen, Y.; Atobe, M.; Fuchigami, T. Org. Lett. 2004, 6, 2441-2444. doi:10.1021/ol049152f

29. Isokawa, M.; Sano, M.; Kubota, K.; Suzuki, K.; Inagi, S.; Fuchigami, T. J. Electrochem. Soc. 2017, 164, G121-G127. doi:10.1149/2.1601713jes

30. Riyadh, S. M.; Ishii, H.; Fuchigami, T. Tetrahedron 2002, 58, 5877-5883. doi:10.1016/S0040-4020(02)00559-8

31. Lee, E.-S.; Choi, B.-W.; Jung, D.-I.; Hwang, H.-J.; Han, J.-T.; Lee, B.-H. Bull. Korean Chem. Soc. 2003, 24, 243-245. doi:10.5012/bkcs.2003.24.2.243

32. Qiao, Z.; Jiang, X. Org. Lett. 2016, 18, 1550-1553. doi:10.1021/acs.orglett.6b00324

33. Ogawa, K. A.; Boydston, A. J. Org. Lett. 2014, 16, 1928-1931. doi:10.1021/ol500459x

34. Lu, G.-p.; Cai, C. Adv. Synth. Catal. 2013, 355, 1271-1276. doi:10.1002/adsc.201201059

35. Moon, H. K.; Sung, G. H.; Kim, B. R.; Park, J. K.; Yoon, Y.-J.; Yoon, H. J. Adv. Synth. Catal. 2016, 358, 1725-1730. doi:10.1002/adsc.201501177

36. Montenegro, E.; Echarri, R.; Claver, C.; Castillón, S.; Moyano, A.; Pericàs, M. A.; Riera, A. Tetrahedron: Asymmetry 1996, 7, 3553-3558. doi:10.1016/S0957-4166(96)00463-6

37. Oya, M.; Baba, T.; Kato, E.; Kawashima, Y.; Watanabe, T. Chem. Pharm. Bull. 1982, 30, 440-461. doi:10.1248/cpb.30.440

38. Beckwith, A. L. J.; Duggan, S. A. M. J. Chem. Soc., Perkin Trans. 2 1994, 1509-1518. doi:10.1039/P29940001509

39. Beaulieu, F.; Beauregard, L.-P.; Courchesne, G.; Couturier, M.; LaFlamme, F.; L'Heureux, A. Org. Lett. 2009, 11, 5050-5053. doi:10.1021/ol902039q

40. Bildsoe, H.; Schaumburg, K. J. Magn. Reson. 1974, 14, 223-234. doi:10.1016/0022-2364(74)90275-3

41. Birrell, J. A.; Desrosiers, J.-N.; Jacobsen, E. N. J. Am. Chem. Soc. 2011, 133, 13872-13875. doi:10.1021/ja205602j 


\section{License and Terms}

This is an Open Access article under the terms of the Creative Commons Attribution License

(http://creativecommons.org/licenses/by/4.0), which permits unrestricted use, distribution, and reproduction in any medium, provided the original work is properly cited.

The license is subject to the Beilstein Journal of Organic Chemistry terms and conditions:

(https://www.beilstein-journals.org/bjoc)

The definitive version of this article is the electronic one which can be found at:

doi:10.3762/bjoc. 14.27 